\title{
Comparison of the virulence of Streptococcus pneumoniae in ICR mouse stocks of three different origins
}

\author{
Jun-Young Kim, Sun-Min Seo, Han-Kyul Lee, Han-Woong Kim and Yang-Kyu Choi* (D)
}

\begin{abstract}
Streptococcus pneumoniae causes many people to suffer from pneumonia, septicemia, and other diseases worldwide. To identify the difference in susceptibility of and treatment efficacy against $S$. pneumoniae in three ICR mouse stocks (Korl: $I C R, A: I C R$, and B:ICR) with different origins, mice were infected with $2 \times 10^{6}, 2 \times 10^{7}$, and $2 \times 10^{8}$ CFU of $S$. pneumoniae D39 intratracheally. The survival of mice was observed until three weeks after the infection. The three stocks of mice showed no significant survival rate difference at $2 \times 10^{6}$ and $2 \times 10^{7} \mathrm{CFU}$. However, the lung and spleen weight in the A:ICR stock was significantly different from that in the other two stocks, whereas the liver weight in B:ICR stock was significantly lower than that in the other two stocks. Interestingly, no significant CFU difference in the organs was observed between the ICR stocks. The level of interferon gamma inducible protein 10 in Korl:ICR was significantly lower than that in the other two stocks. The level of granulocyte colony stimulating factor in B:ICR was significantly lower than in the other two stocks. However, tumor-necrosis factor-alpha and interleukin-6 levels showed no significant difference between the ICR stocks. In the vancomycin efficacy test after the S. pneumoniae infection, both the single-dose and double-dose vancomycin-treated groups showed a significantly better survival rate than the control group. There was no significant survival difference between the three stocks. These data showed that Korl:ICR, A:ICR, and B:ICR have no susceptibility difference to the S. pneumoniae D39 serotype 2.
\end{abstract}

Keywords: Streptococcus pneumonia D39, Vancomycin, Survival rate

\section{Introduction}

Streptococcus pneumonia is a gram-positive pathogen that affects humans $[1,2]$. The treatment for infection with S. pneumoniae requires taking antibiotics. This pathogen causes several infectious diseases such as pneumonia, meningitis [3], and acute otitis media [4] and acute sinusitis [5].

The occurrence of pneumococcal and acute respiratory infections is decreasing but is still considerably high in children under the age of 5 and in elders with weak immunity, in developing countries. Approximately 20-25\% of all mortalities in children are identified to be a bacterial pneumonia caused by S. pneumoniae [4, 6]. The pathogen normally occupies the nasopharynx. The use of antibiotics in the treatment of the disease is impeded by the increase

\footnotetext{
* Correspondence: yangkyuc@konkuk.ac.kr

Department of Laboratory Animal Medicine, College of Veterinary Medicine, Konkuk University, 120 Neungdong-ro, Gwangjin-gu, Seoul 05029, Republic
} of Korea

(c) The Author(s). 2019 Open Access This article is distributed under the terms of the Creative Commons Attribution 4.0 International License (http://creativecommons.org/licenses/by/4.0/), which permits unrestricted use, distribution, and reproduction in any medium, provided you give appropriate credit to the original author(s) and the source, provide a link to the Creative Commons license, and indicate if changes were made. The Creative Commons Public Domain Dedication waiver (http://creativecommons.org/publicdomain/zero/1.0/) applies to the data made available in this article, unless otherwise stated. Additionally, antibiotics cannot decrease the mortality rate of disease in the first 3 days of treatment, which emphasizes the need for deeper knowledge on the pathogenesis of pneumococcal disease [1]. Despite the high mortality worldwide, the host-pathogen interaction during S. pneumoniae infection is poorly understood and in depth knowledge is required [7].

The significance of animal models is well known especially in studying infectious diseases, as well as treatment efficacies. Animal models allow investigators to simulate various immune states and adjust the severity of infection in vivo, which allows in depth pharmacokinetic and pharmacodynamic measurements [8]. ICR mice are an outbred which Swiss in origin those are used in various field of research study. Multiple suppliers produce their own commercial ICR stocks which lead to characteristic varieties [9]. This study was performed to investigate the difference in the susceptibility of and treatment efficacy 
against S. pneumoniae serotype 2 D39 in differently originated ICR outbred mice.

\section{Materials and methods \\ Animals}

Seven-week-old male ICR mice were obtained from three difference sources. Korl:ICR was obtained from Koatech (Gyeonggi-do, Korea). A:ICR and B:ICR mice were purchased through Orient Bio Inc.(Gyeonggi-do, Korea) and Japan SLC (Shizuoka, Japan), respectively. Mice were acclimatized for a week at the pathogen-free animal facility at the College of Veterinary Medicine, Konkuk University (Seoul, Korea). Five mice were bred per sterilized polycarbonate cage and allowed 24-h access to sterilized food and water, and provided with sterilized wooden bedding. The facility was maintained with 12-h light/dark cycle and the temperature was maintained at $22 \pm 2{ }^{\circ} \mathrm{C}$ and $50 \pm 10 \%$ humidity. The surviving animals after the examination were euthanized in a $\mathrm{CO}_{2}$ gas chamber. All the procedures were approved by the Institutional Animal Care and Use Committee.

\section{Streptococcus pneumoniae D39 preparation}

S. pneumoniae D39 serotype 2 was obtained from the Korean Centers for Disease Control and Prevention (KCDC, Osong, Korea) and stored at $-70^{\circ} \mathrm{C}$. The bacterial cells were placed at room temperature on ice until complete melting and cultured on a $5 \%$ sheep blood agar plate at $37^{\circ} \mathrm{C}$ with $5 \% \mathrm{CO}_{2}$ supplement for $16 \mathrm{~h}$. Bacteria were harvested and re-suspended in sterilized phosphate buffered saline (PBS) to an optical density value of 0.3 . Then the bacteria-PBS stock was transferred to brainheart infusion broth (Merck, Darmstadt, Germany) and incubated at $37^{\circ} \mathrm{C}$ with $5 \% \mathrm{CO}_{2}$ for $6 \mathrm{~h}$. The bacterial solution was centrifuged at $4500 \mathrm{rpm}$ for $5 \mathrm{~min}$. The concentration of bacteria was measured by optical density absorbance value at $600 \mathrm{~nm}$ using spectrometer. Colony forming units (CFU) per $\mu \mathrm{L}$ were counted using sheep blood agar plate with serially diluted bacterial suspension.

\section{Survival rate}

S. pneumoniae D39 stocks were prepared at $2 \times 10^{6}$, $2 \times 10^{7}$, and $2 \times 10^{8} \mathrm{CFU}$. Mice were intraperitoneally anesthetized with a mixture of Ketamine (Yuhan chemical Inc., Seoul, Korea) and Rumpun (Bayer Korea, Seoul, Korea). A total of $30 \mu \mathrm{L}$ of S. pneumoniae suspension $\left(2 \times 10^{6}, 2 \times 10^{7}\right.$, and $\left.2 \times 10^{8} \mathrm{CFU}\right)$ was injected via exposed tracheae using a 31-gauge needle, via intratracheal injection. The skin incision was closed with suture materials. The clinical signs and death of ICR mice ( $n=10$ per group) were observed twice daily and body weight was measured once a day for 21 days after the injection of bacteria.

\section{Pathogenicity test}

Three ICR stocks ( $\mathrm{n}=10$ per group) were injected with $30 \mu \mathrm{L}$ of $2 \times 10^{6} \mathrm{CFU}$ S. pneumoniae D39 intra-tracheally after anesthetization. The mice underwent autopsy at $48 \mathrm{~h}$ after the infection. Blood samples were collected via caudal vena cava and stored at $-4{ }^{\circ} \mathrm{C}$ overnight for serum separation. Liver, spleen, and lung were harvested and weighed in sterile conditions. Each organ was divided into two at each lobe; one half of the organ was immersed into liquid nitrogen and stored in a deep freezer $\left(-70^{\circ} \mathrm{C}\right)$ and the other half was homogenized with sterile PBS for CFU analysis immediately after the extraction.

\section{Vancomycin efficacy test}

Each ICR stock was injected with $30 \mu \mathrm{L}$ of $2 \times 10^{6} \mathrm{~S}$. pneumoniae D39 intratracheally. The vancomycin single-dose treatment group $(n=6)$ of each ICR stock was treated with $30 \mathrm{mg} / \mathrm{kg}$ of vancomycin at $18 \mathrm{~h}$ after infection. Vancomycin double-dose treatment group $(\mathrm{n}=6)$ was treated with $30 \mathrm{mg} / \mathrm{kg}$ of vancomycin at both $18 \mathrm{~h}$ and $42 \mathrm{~h}$ after infection. The control group $(n=10)$ was treated with PBS at both $18 \mathrm{~h}$ and $42 \mathrm{~h}$ after infection. The clinical signs and death of ICR mice were observed twice daily and body weight was measured once a day for 21 days after the injection of bacteria.

\section{CFU analysis}

The liver, spleen, and lung tissues were weighed $(30 \mathrm{mg})$ and homogenized with four times the titer of sterile PBS and subjected to serial dilution. The diluted homogenates were spread on $5 \%$ sheep blood agar plate and incubated for $24 \mathrm{~h}$ at $37^{\circ} \mathrm{C}$ with $5 \% \mathrm{CO}_{2}$. The S. pneumoniae colonies were then counted.

\section{Enzyme-linked immunosorbent assay (ELISA)}

Blood serum was separated by centrifugation from the collected blood samples. The levels of the cytokines tumor necrosis factor- $\alpha$ (TNF- $\alpha$ ), interleukin 6 (IL-6), interferon gamma inducible protein 10 (IP-10), and granulocyte colony stimulating factor (G-CSF) were measured using the Duoset ELISA kit (R\&D systems, Minneapolis, MN) by following the manufacturers' instruction. Blood serum was 1:5 in diluent buffer. The cytokine levels were analyzed using corresponding standard curve, and measurement of absorbance at $450 \mathrm{~nm}$ and $570 \mathrm{~nm}$.

\section{Statistical analyses}

Analyses of the data were performed through Prism 5 (Graphpad Software Inc.). Quantitative data are expressed as the mean values with standard deviation. Log-rank test was used to determine the survival difference and the significant difference between the groups was analyzed by the two-tailed Student's $t$-test. The value of $P<0.05$ was considered to be statistically significant. 


\section{Results}

Survival rate examination in the different mouse stocks To identify the survival difference among the three different mouse stocks, the survival rate was measured for 3 weeks after the S. pneumoniae D39 infection. When mice were infected with $2 \times 10^{6} \mathrm{CFU}$ bacteria, death in all the three stocks began at day 2 after the infection. The final survival percentage for Korl:ICR, A:ICR, and B:ICR was 10, 20, and 10\%, respectively. No significant difference was observed between the stocks. When the mice were infected with $2 \times 10^{7} \mathrm{CFU}$ bacteria, the A:ICR and B: ICR groups exceeded $50 \%$ mortality at day 2 followed by Korl:ICR at day 5. None of the Korl:ICR mice survived, while $10 \%$ of A:ICR and B:ICR survived at the end of the experiment. No significant difference was observed between the stocks. When the mice were infected with $2 \times 10^{8}$ CFU bacteria, $90 \%$ of the B:ICR mice died by day 2 after infection. Only $10 \%$ of the A:ICR mice survived till the end of experiment, while the other two stocks showed 0\% survival. Significant difference was observed between Korl:ICR and B:ICR $(P<0.001)$, and A:ICR and B:ICR $(P<0.01)$ (Fig. 1).

\section{Pathogenicity examination in the different mouse stocks}

As shown in Fig. 2, the weight of each organ per body weight (\%) varied among the different stocks. The lung weight in the A:ICR group was significantly heavier than in the other two stocks $(P<0.05)$ (Fig. 2a). The spleen weight was significantly lower in the A:ICR group $(P<0.05)$ (Fig. $2 \mathrm{c})$ whereas the liver weight was significantly lower in the B:ICR group than in the other two stocks $(P<0.05)$ (Fig. 2e). On counting the bacterial numbers in each organ, more than $10^{4} \mathrm{CFU} / \mathrm{g}$ of $S$. pneumoniae D39 were calculated in the lung, spleen and liver of all three stocks. However, no significant difference was observed in the lung (Fig. 2b), spleen (Fig. 2d), and liver (Fig. 2f) between the groups. Hence, the organ per body weight did not influence the bacterial numbers to be greater or lesser in the organs.

TNF- $\alpha$, IL-6, IP-10, and G-CSF cytokine levels were measured via ELISA using blood serum. The TNF- $\alpha$ and IL-6 levels were highest in the A:ICR group; however, no significant difference was observed between the stocks. The IP-10 level was significantly lower in the Korl:ICR group compared to the A:ICR $(P<0.05)$ and B:ICR $(P<0.01)$ groups. The serum G-CSF level was significantly lower in the B:ICR group than in the other two groups $(P<0.05)$ (Fig. 3$)$.

\section{Effect of vancomycin treatment in the different mouse stocks}

To identify treatment susceptibility of the mouse stocks, $30 \mathrm{mg} / \mathrm{kg}$ of vancomycin was injected at $18 \mathrm{~h}$ or $18,42 \mathrm{~h}$ after the bacterial infection. The death of mice in the
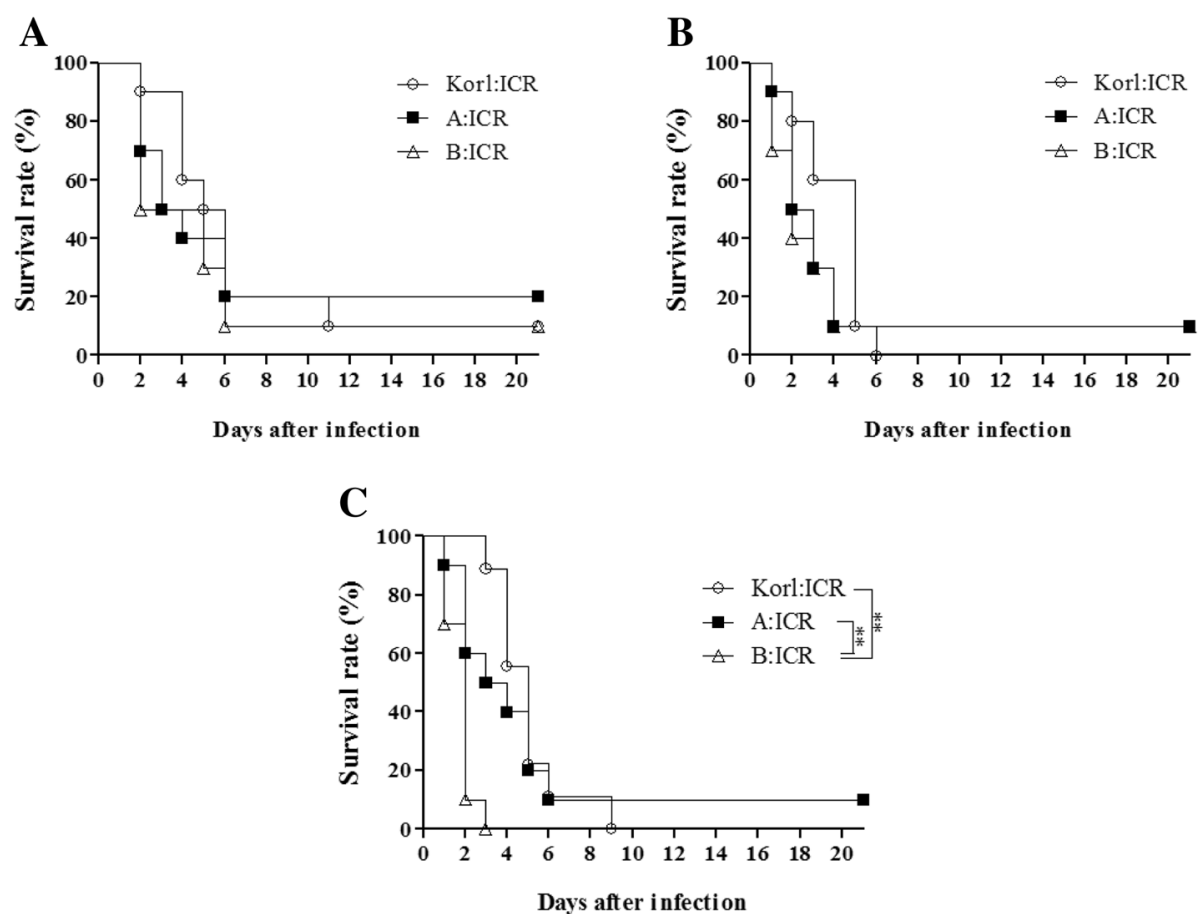

Fig. 1 Survival rates (\%) of Korl:ICR, A:ICR, and B:ICR stocks infected with S. pneumoniae D39 serotype 2 with CFU of $2 \times 10^{6}$ (a), $2 \times 10^{7}$ (b) and $2 \times 10^{8}$ (c). Significant death rate of mice in B:ICR than in Korl:ICR and A:ICR was observed only at $2 \times 10^{8} \mathrm{CFU}(P<0.01)$. $P$ values were calculated by the log-rank test 

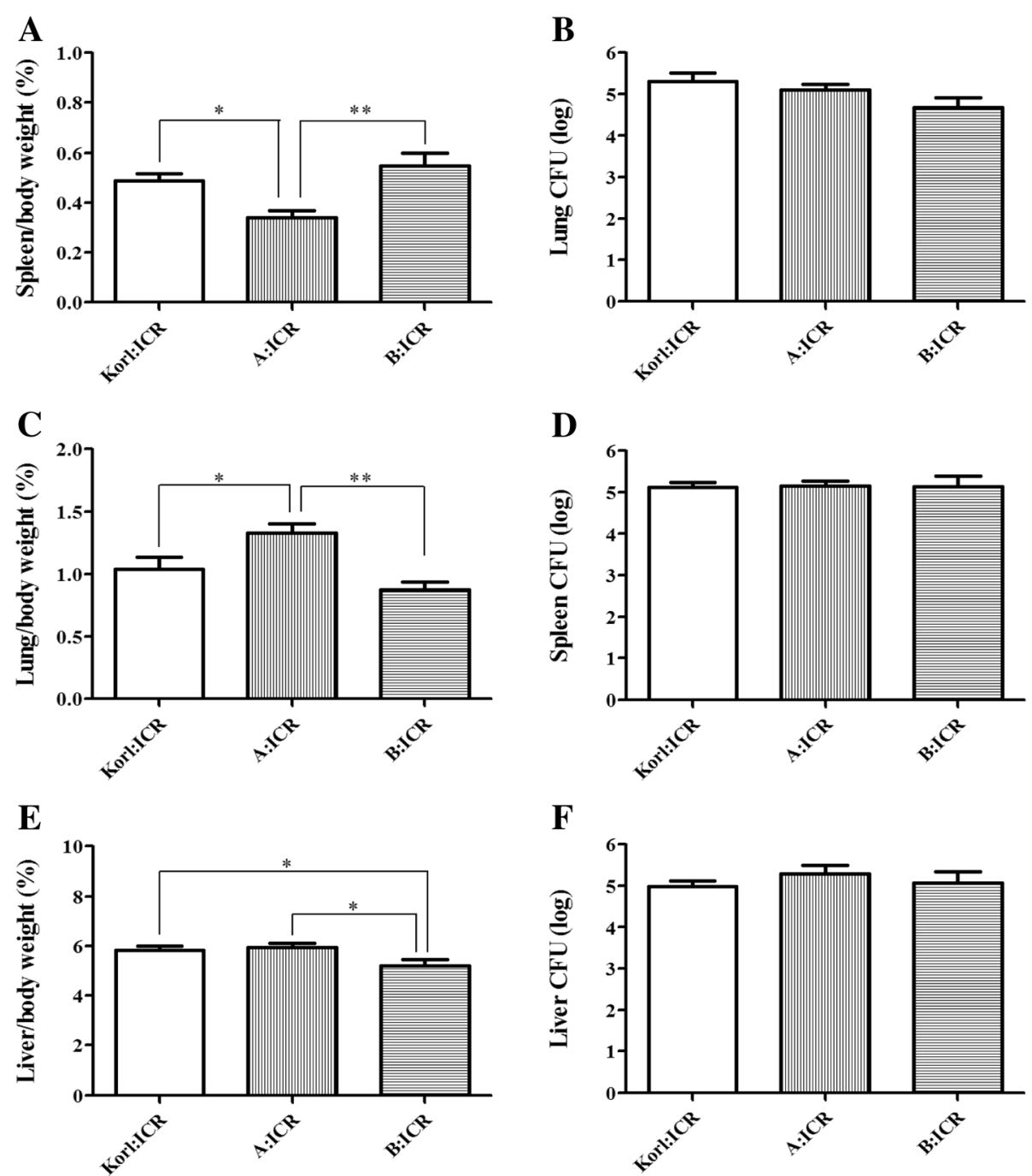

Fig. 2 Weight of the lung (a), spleen (c), and liver (e) compared to the body weight (\%) and CFU (log)/g of the lung (b), spleen (d), and liver (f) were measured 2 days after infection with $2 \times 10^{6} \mathrm{CFU}$ of S. pneumoniae D39 serotype 2. Lung and spleen weight in A:ICR were significantly different than in Korl:ICR and B:ICR. Liver weight in B:ICR was significantly lower than in Korl:ICR and A:ICR. Data are expressed as the mean \pm SD. ${ }^{*} P<0.05,{ }^{*} P<0.01$ between the ICR stocks using two tailed $t$-tests

control group began at 2 days after the infection and $100 \%$ mice died before the end of the experiment. However, the mice in the vancomycin double-dose group ( $18 \mathrm{~h}$ and $42 \mathrm{~h}$ after infection) were alive with 80,50 , and $60 \%$ surviving at the end of experiment in the Korl:ICR, A:ICR, and B:ICR group, respectively. In all the mouse stocks, the vancomycin single-dose and vancomycin double-dose treatment groups showed significantly better survival than the control group $(P<0.05)$. Furthermore, even though the double-dose treatment group had higher survival rate than the single-dose treatment group, significant $(P<0.05)$ difference was observed between these treatment groups in the A:ICR mice only (Fig. 4).

\section{Discussion}

S. pneumoniae infection is fatal in children living in developing countries [10] and the entire population is at risk of suffering from pneumococcus infection throughout their life time [1]. Many studies use murine models to investigate the pneumococcal bacteria that cause pneumonia. This study was identified the susceptibility and treatment efficacy differences against $S$. pneumoniae serotype 2 D39 between Korl:ICR, A:ICR, and B:ICR sources.

A total of $2 \times 10^{6}, 2 \times 10^{7}$, and $2 \times 10^{8} \mathrm{CFU}$ doses of $S$. pneumoniae were inoculated via intratracheal injection. The onset of death started 1 day after the infection with $2 \times 10^{7}$ and $2 \times 10^{8} \mathrm{CFU}$ and from day 2 with $2 \times 10^{6}$ CFU. The numbers of surviving mice at 21 days after 

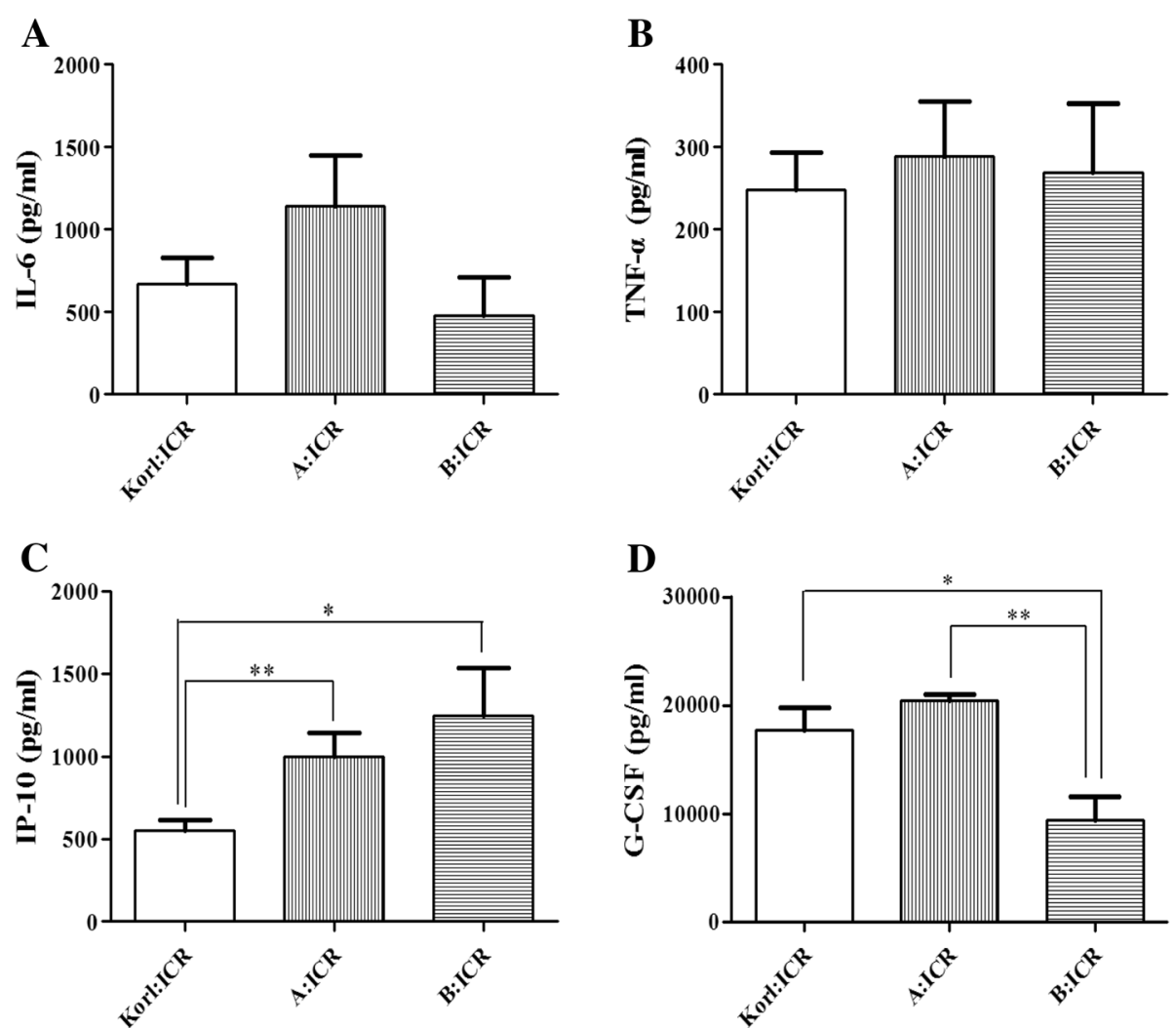

Fig. 3 Serum cytokine levels of tumor necrosis factor-a (TNF-a) (a), interleukin 6 (IL-6) (b), interferon gamma inducible protein 10 (IP-10) (c), and granulocyte colony stimulating factor (G-CSF) (d) were measured 2 days after infection with $2 \times 10^{6}$ CFU of S. pneumoniae D39 serotype 2. IP-10 level in Korl:ICR was significantly lower than in other ICR stocks. G-CSF level in B:ICR was significantly lower than in other ICR stocks. Data are expressed as the mean \pm SD. ${ }^{*} P<0.05,{ }^{* *} P<0.01$ between the ICR stocks using two tailed $t$-tests

infection with the CFU doses $2 \times 10^{6}, 2 \times 10^{7}$ and $2 \times 10^{8}$ were 4, 2, and 1, respectively. As shown in Fig. 1, the higher CFU value showed more rapid and vigorous death. Upon infection with $2 \times 10^{8} \mathrm{CFU}$, the B:ICR mice showed a significantly higher death rate compared to the Korl:ICR and A:ICR stocks. In the other study, S. pneumoniae infection with $2 \times 10^{6} \mathrm{CFU}$, also showed no significant susceptibility difference between $\mathrm{C} 3 \mathrm{H} / \mathrm{HeN}, \mathrm{C} 57 \mathrm{BL} / 6$, and ICR [11].

The A:ICR stock showed a significantly higher lung weight and lower spleen weight compared to the Korl: ICR and B:ICR mice $(P<0.05)$. However, the liver weight was significantly lower in the B:ICR mice. Usually, the enlargement of spleen caused by pathogen-induced hyperplasia [12] can be the hallmark of severity of a disease and the lung weight considerably increases in the case of severe pneumonia [13]. However, CFU analysis revealed no significant bacterial level differences in the spleen, lung, and liver between the three ICR stocks.

Cytokines such as tumor necrosis factor-alpha (TNF- $\alpha$ ) and interleukin- 6 (IL-6) are found at high concentration upon tissue injury or bacteria-induced organ damage [14], and has a role in bacterial clearance in pulmonary infection $[15,16]$. In addition, TNF- $\alpha$ reduced the thymocyte apoptosis against S. pneumonia infection [17]. When BALB/c and C57BL/6 mice were infected with the $S$. pneumoniae serotype 3 WU2, spleen cytokine levels showed no alteration whereas infection with the S. pneumoniae serotype 14 DW14 in the same mice strains showed alteration of cytokine levels [18]. The pro-inflammatory cytokine IP-10 level was elevated by S. pneumoniae and Neisseria meningitides [19]. In $2 \times 10^{8}$ CFU S. pneumoniae infection, survival rate of B:ICR was also significantly lower than the other two stocks (Fig. 1c). G-CSF assists neutrophils to be released into blood from bone marrow [20] and mice with deficient G-CSF receptor were highly sensitive to fungal and bacterial infection [21]. In case of mice infected with $2 \times 10^{6} \mathrm{CFU}$ of $S$. pneumoniae, high level of serum G-CSF after 2 days of infection in Korl:ICR and A:ICR mice was closely associated with an increase of survival rate (Figs. 1a and 3d). These results are similar to previous reports that G-CSF pretreatment in mice and rats increased the survival rate in S. pneumoniae infection $[22,23]$. TNF- $\alpha$ and IL-6 levels were not significantly different between the three ICR stocks, while Korl:ICR showed a significantly lower IP-10 level than the 

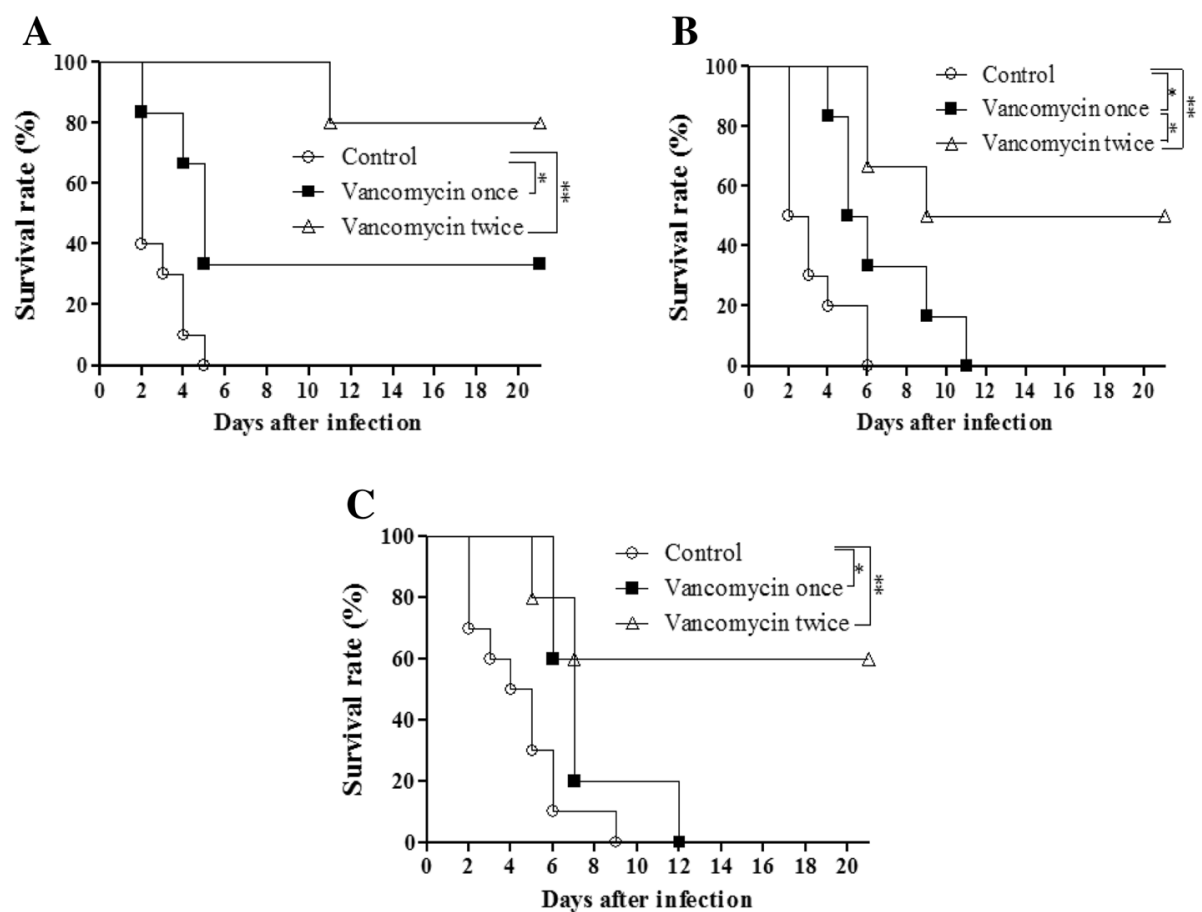

Fig. 4 Survival rates (\%) of Korl:ICR (a), A:ICR (b), and B:ICR (c) were observed after infection with $2 \times 10^{6}$ CFU S. pneumoniae D39 serotype 2. These mice were treated with vancomycin single-dose or double-dose after $18 \mathrm{~h}$, or 18 and $42 \mathrm{~h}$. Treatment with vancomycin significantly improved the survival rate than that of the control mice in all the stocks $(P<0.05)$. Repetition of vancomycin injection enhanced the survival, while only A:ICR exhibited significantly improved survival rate in $18,42 \mathrm{~h}$ than in the $18 \mathrm{~h}$ vancomycin treatment $(P<0.05)$. $P$ values were calculated by the log-rank test. ${ }^{*} P<0.05,{ }^{* *} P<0.01$ between the groups

other two ICR stocks. G-CSF level in B:ICR was significantly lower than the other two stocks.

Vancomycin is a glycopeptide antibiotic that inhibits gram-positive bacteria, and leads to decrease in IL-17producing T-helper cells (Th17), which are potent inflammatory activators [24]. A vancomycin single-dose of $30 \mathrm{mg} / \mathrm{kg}$ and double-dose treatment after bacterial injection significantly increased the survival rate compared to that in the control group in all the ICR stocks. However, only the A:ICR stock showed a significantly better survival rate between the single-dose and double-dose vancomycin treatments. The A:ICR and B:ICR stocks treated with single-dose vancomycin showed $100 \%$ mortality; however, Korl:ICR showed $70 \%$ mortality. Thirty-three percent survived in Korl:ICR but no significant survival rate difference between the stocks was observed. The double-dose vancomycin treatment showed 80,50 , and $70 \%$ survival rate in Korl:ICR, A:ICR, and B:ICR, respectively. We found that the Korl:ICR stock was more sensitive to the antibiotic than the other ICR stocks. Repeated antibiotic treatment enhanced the survival rate of the three different stocks. Further study is needed to increase the survival rate beyond that obtained in the current study. Based on our results, due to the characteristics of the outbred ICR along with their different origins, the relative weight of the organs and the cytokine levels may vary, but the severity of infection caused by S. pneumoniae serotype 2 D39 was not significantly affected, except at high dose of bacterial load. Moreover, the repeated treatment with antibiotics increased the survival rate. Taken together, the Korl:ICR, A:ICR and B:ICR stocks have no difference in susceptibility to the S. pneumoniae D39 serotype 2 and this response profile may help other researchers searching for an ICR animal model in the future.

\section{Conclusion}

Three ICR mice stocks (Korl:ICR, A:ICR, and B:ICR) of mice showed no significant survival rate difference when mice were infected with at $2 \times 10^{6}$ and $2 \times 10^{7} \mathrm{CFU}$. And TNF- $\alpha$ and IL- 6 levels showed no significant difference between the ICR stocks. However, Korl:ICR mice showed a significantly lower IP-10 level while B:ICR mice showed a significantly lower G-CSF level than the other two stocks. Our results indicate that there is no susceptibility difference to $S$. pneumonia D39 serotype 2 upon three different ICR stocks.

\section{Abbreviations}

CFU: Colony forming unit; ELISA: Enzyme linked immunosorbent assay; G-CSF: Granulocyte colony stimulating factor; IL-6: Interleukin 6; IP-

10: Interferon gamma inducible protein 10; PBS: Phosphate buffered saline; S. pneumoniae: Streptococcus pneumonia; Th17: IL-17 producing T-helper cell; TNF- a: Tumor necrosis factor- $a$ 


\section{Acknowledgements}

Not applicable.

\section{Funding}

This project was supported by a grant of NLAR (National Laboratory Animal Resources) from Ministry of Food and Drug Safety in 2018.

\section{Availability of data and materials}

All data produced or analyzed during the current investigation are available from the corresponding author on reasonable request.

\section{Authors' contributions}

JYK, HWK, HKL and SMS performed experiments. JYK, HWK and CYK analyzed results. JYK and CYK prepared the Figures. CYK designed the research. JYK and CYK wrote the manuscript. All authors read and approved the final manuscript.

\section{Competing interests}

The authors declare that they have no competing interests.

Received: 15 March 2019 Accepted: 11 April 2019

Published online: 24 June 2019

\section{References}

1. Kadioglu A, Andrew PW. The innate immune response to pneumococcal lung infection: the untold story. Trends Immunol. 2004:25(3):143-9.

2. Kharat AS, Tomasz A. Inactivation of the srtA gene affects localization of surface proteins and decreases adhesion of Streptococcus pneumoniae to human pharyngeal cells in vitro. Infect Immunol. 2003;71(5):2758-65.

3. Mitchell TJ, Alexander JE, Morgan PJ, Andrew PW. Molecular analysis of virulence factors of Streptococcus pneumoniae. J Appl Microbiol. 1997;83(S1):62S-71S.

4. Gianfaldoni C, Censini S, Hilleringmann M, Moschioni M, Facciotti C, Pansegrau W, Masignani V, Covacci A, Rappuoli R, Barocchi MA, Ruggiero P. Streptococcus pneumoniae pilus subunits protect mice against lethal challenge. Infect Immun. 2007;75(2):1059-62.

5. Garcia-Suarez Mdel M, Cima-Cabal MD, Florez N, Garcia P, Cernuda-Cernuda R, Astudillo A, Vazquez F, De los Toyos JR, Mendez FJ. Protection against pneumococcal pneumonia in mice by monoclonal antibodies to pneumolysin. Infect Immun. 2004;72(8):4534-40.

6. Berkley JA, Lowe BS, Mwangi I, Williams T, Bauni E, Mwarumba A, Ngesta C, Slack Mary PE, Njenga S, Hart CA, Maitland K, English M, Marsh K, Scott JAG. Bacteremia among children admitted to a rural hospital in Kenya. N Engl J Med. 2005:352:39-47.

7. Jeong DG, Seo JH, Heo SH, Choi YK, Jeong ES. Tumor necrosis factor-alpha deficiency impairs host defense against Streptococcus pneumoniae. Lab Anim Res. 2015;31(2):78-85.

8. Andes D, Craig WA. Animal model pharmacokinetics and pharmacodynamics: a critical review. Int J Antimicrob Agents. 2002;19(4):261-8.

9. Kim SH, Kim KJ, Kim JH, Kwak JH, Song H, Cho JY, Hwang DY, Kim KS, Jung YS. Comparison of doxorubicin-induced cardiotoxicity in the ICR mice of different sources. Lab Anim Res. 2017;33(2):165-70.

10. Levine OS, O'Brien KL, Knoll M, Adegbola RA, Black S, Cherian T, Dagan R, Goldblatt D, Grange A, Greenwood B, Hennessy T, Klugman KP, Madhi SA, Mulholland K, Nohynek H, Santosham M, Saha SK, Scott JA, Sow S, Whitney CG, Cutts F. Pneumococcal vaccination in developing countries. Lancet. 2006:367(9526):1880-2

11. Takashima K, Tateda K, Matsumoto T, Ito T, Ilzawa Y, Nakao M, Yamaguchi K. Establishment of a model of penicillin-resistant Streptococcus pneumoniae pneumonia in health CBA/J mice. J Med Microbiol. 1996;45:319-22.

12. Kono DH, Burlingame RW, Owens DG, Kuramochi A, Balderas RS, Balomenos D, Theofilopoulos AN. Lupus susceptibility loci in New Zealand mice. Proc Natl Acad Sci U S A. 1994;91(21):10168-72.

13. Van der Poll T, Keogh CV, Buurman WA, Lowry SF. Passive immunization against tumor necrosis factor-a impairs host defense during pneumococcal pneumonia in mice. Am J Respir Crit Care Med. 1997;155:603-8.

14. Tracey KJ, Fong Y, Hesse DG, Manogue KR, Lee AT, Kuo GC, Lowry SF, Cerami A. Anti-cachectin/TNF monoclonal antibodies prevent septic shock during lethal bacteraemia. Nature. 1987;330(6149):662-4.
15. Gosselin D, DeSanctis J, Boule M, Skamene E, Matouk C, Radzioch D. Role of tumor necrosis factor alpha in innate resistance to mouse pulmonary infection with Pseudomonas aeruginosa. Infect Immun. 1995;63(9):3272-8.

16. Puren AJ, Feldman C, Savage N, Becker PJ, Smith C. Patterns of cytokine expression in community-acquired pneumonia. Chest. 1995;107(5):1342-9.

17. Wang SD, Huang KJ, Lin YS, Lei HY. Sepsis-induced apoptosis of the thymocytes in mice. J Immunol. 1994;152(10):5014-21.

18. Mizrachi-Nebenzahl Y, Lifshitz S, Teitelbaum R, Novick S, Levi A, Benharroch D, Ling E. Differential activation of the immune system by virulent Streptococcus pneumoniae strains determines recovery or death of the host. Clin Exp Immunol. 2003:134(1):23-31.

19. Mogensen TH, Paludan SR, Kilian M, Ostergaard L. Live Streptococcus pneumoniae, Haemophilus influenzae, and Neisseria meningitidis activate the inflammatory response through toll-like receptors 2, 4, and 9 in speciesspecific patterns. J Leukoc Biol. 2006:80(2):267-77.

20. Semerad CL, Liu F, Gregory AD, Stumpf K, Link DC. G-CSF is an essential regulator of neutrophil trafficking from the bone marrow to the blood. mmunity. 2002;17(4):413-23.

21. Hermans $\mathrm{MH}$, Ward AC, Antonissen C, Karis A, Lowenberg B, Touw IP. Perturbed granulopoiesis in mice with a targeted mutation in the granulocyte colony-stimulating factor receptor gene associated with severe chronic neutropenia. Blood. 1998:92(1):32-9.

22. Brandt CT, Lundgren JD, Lund SP, Frimodt-Møller N, Christensen T, Benfield T, Espersen F, Hougaard DM, Østergaard C. Attenuation of the bacterial load in blood by pretreatment with granulocyte-colony-stimulating factor protects rats from fatal outcome and brain damage during Streptococcus pneumoniae meningitis. Infect Immun. 2004;72(8):4647-53.

23. Hebert JC, O'Reilly M, Yuenger K, Shatney L, Yoder DW, Barry B. Augmentation of alveolar macrophage phagocytic activity by granulocyte colony stimulating factor and interleukin-1: influence of splenectomy. J Trauma. 1994:37(6):909-12

24. Ivanov II, Frutos Rde L, Manel N, Yoshinaga K, Rifkin DB, Sartor RB, Finlay BB, Littman DR. Specific microbiota direct the differentiation of IL-17-producing T-helper cells in the mucosa of the small intestine. Cell Host Microbe. 2008;4(4):337-49.

\section{Publisher's Note}

Springer Nature remains neutral with regard to jurisdictional claims in published maps and institutional affiliations.

Ready to submit your research? Choose BMC and benefit from:

- fast, convenient online submission

- thorough peer review by experienced researchers in your field

- rapid publication on acceptance

- support for research data, including large and complex data types

- gold Open Access which fosters wider collaboration and increased citations

- maximum visibility for your research: over $100 \mathrm{M}$ website views per year

At BMC, research is always in progress.

Learn more biomedcentral.com/submissions 